\title{
CITAÇÃO E AUTORIA EM BREVES NOTAS SOBRE AS LIGAÇÕES [LLANSOL, MOLDER E ZAMBRANO], DE GONÇALO M. TAVARES
}

\author{
CITATION AND AUTHORSHIP IN BREVES \\ NOTAS SOBRE AS LIGAÇÕES [LLANSOL, \\ MOLDER E ZAMBRANO], \\ BY GONÇALO M. TAVARES
}

Madalena Vaz Pinto ${ }^{1}$

\begin{abstract}
RESUMO
Tem-se discutido pouco o fato dos textos de Gonçalo M. Tavares requererem modos de aproximação particulares não firmados por pactos de leitura tradicionais. Decorre este fato de se tratar de textos construídos por formas discursivas variadas, com opção recorrente pelo fragmento e uso da citação, nos quais a autoria se manifesta de forma polifónica e não totalizadora. Este trabalho visa discutir estes aspectos em Breves notas sobre as ligações (Llansol, Molder e Zambrano).
\end{abstract}

PALAVRAS-CHAVE: fragmento, citação, autoria

\section{ABSTRACT}

Little has been discussed concerning the fact that Gonçalo M. Tavares's texts demand from his readers non-conventional approaches. He uses different discursive strategies, appealing to citations and fragments in which autorship is a poliphonic and non-totalizing entity. This article will work out those aspects of his literature focusing in one of his books: Breves notas sobre as ligações (Llansol, Molder e Zambrano).

KEYWORDS: fragment, citation, autorship. 
Ou: estou vivo: estou obrigado a ligar-me .

Breves notas sobre as ligações (Llansol, Molder e Zambrano) ${ }^{2}$ é um dos livros de Gonçalo M. Tavares em que a citação está presente de forma mais explícita e convencional: entre aspas. Trata-se de um livro composto por um conjunto de fragmentos de dimensões variadas, escritos a partir de citações de três autoras: Maria Gabriela Llansol, Maria Filomena Molder e María Zambrano.

"A partir" designa aqui uma tentativa de descrição da organização espacial do texto em que cada fragmento é precedido por uma citação entre aspas de cada uma das autoras, seguida do texto do próprio autor. Não é uma definição que possa, por si só, se constituir como chave de leitura e funcionar como possível orientação na abordagem do texto. Os textos são neutros e impessoais. Todavia, nesse mesmo tom impessoal, algumas indicações vão sendo dadas sobre o propósito que orientou essa construção, fundado na ideia de um estilo próprio, pautado pelo atravessamento de vozes outras que destituem a autoridade da voz do autor. Elas estão presentes desde as epígrafes que antecedem o texto. Primeira: "Este livro é obviamente dedicado a María Zambrano, Maria Filomena Molder e Maria Gabriela Llansol, três escritoras cuja leitura exige de nós uma resposta, um movimento paralelo, uma deslocação" (TAVARES, 2009, s/n.). Segunda: "O comentário do paralelista é tão ilimitado como ilimitado é o texto; e o texto, quer seja atravessado na sua estrutura de lugar dos ecos, quer seja tratado como labirinto de todos os itinerários possíveis, é absolutamente ilimitado" (TAVARES, 2009, s/n.). Escrita entre aspas, esta epígrafe é também a primeira citação do livro, do escritor de vanguarda italiano Giorgio Manganelli, ${ }^{3}$ e constitui uma primeira e importante chave de leitura, não só para este texto, mas para o procedimento geral que orienta o processo criativo de Gonçalo M. Tavares. O texto é ilimitado, assim como ilimitado é o seu comentário. Tais pistas, portanto, servem ao mesmo tempo como teoria da escrita e teoria da leitura. O ilimitado, neste caso, não é unicamente quantitativo, possibilidade infinita de um texto gerar outros textos, mas tem um valor ontológico de base, na veemente negação de um valor de verdade que o texto visasse apresentar.

O uso da citação é um dos procedimentos que sinalizaram uma alteração na forma de criação artística e literária, deslocando a ideia de uma autoria autônoma e original, para uma autoria que se constrói com, no gesto de apropriação de um texto, de um objeto, de uma imagem. Trata-se de um procedimento bastante difundido hoje, entre escritores e artistas, o que pode ser relacionado às novas tecnologias que disponibilizam 
um número de textos e imagens prontos para serem deslocados e apropriados, maior do que alguma vez antes. Parece haver, na base do gesto de apropriação, do qual a citação é uma das formas, uma atitude anterior, des-essencializadora, quer da pureza do meio, quer da ideia de autoria. Se a arte quer ser do seu tempo, deve encontrar maneiras de estar nele, de reinventar modos de criação e difusão. Parece ter sido isso que Benjamin tão bem percebeu, quando apontou a quebra da aura e a reprodutibilidade técnica como meios mais condizentes com as mudanças de percepção que a modernização dos sentidos provocava (BENJAMIN, 1992).

Nesse processo, fundamentos e essências são abalados, e esse nos parece ser o caso dos textos escritos por Gonçalo M. Tavares, ao transportarem em seu interior a pergunta "O que é literatura ?" - e fazerem dela sua potência. É o caso do texto que aqui nos ocupa, apropriação-diálogo de textos de três autoras, duas filósofas e uma escritora, autora, ela também, de textos polifónicos, habitados por vozes e revisitações. Essa conjunção, portanto, não parece ser aleatória, nem o texto que daí resulta pode ser dissociado da problematização do estatuto do literário, muito pelo contrário, dele se alimenta: "Não há literatura" diz Llansol, "Quando se escreve só importa saber em que real se entra, e se há técnica adequada para abrir caminhos a outros" (LLANSOL, 1998, p. 55).

A citação é uma forma de abertura, de reconhecimento, de produção de polifonia. Toda a citação, diz Compagnon "é primeiro uma leitura", (COMPAGNON, 2007, p. 19) e, no gesto duplo que a caracteriza, extirpação-enxerto, no corpoacorpo com outros textos, resulta em uma reescrita, em um estabelecer de ligações. A citação, isolada, não tem sentido, ela só adquire sentido quando incide sobre outro texto, o faz agir. Citar para, como em Breves notas sobre as ligações, ligar:

Como é que as coisas se ligam? Como é que as coisas se começam a amar ou odiar? [...]

Diz MFM: "A ordem desordenada destas reuniões do acaso traz consigo a marca do essencial."

$[\ldots]$

Porque os acasos são mais importantes do que a vontade ou a intenção. Porque intenção e vontade são humanas; o acaso, esse, desconhecemos de onde vem.

Método é aquilo que se faz depois de se ter tropeçado (TAVARES, 2009, p. 71).

A atividade metódica existe, não se trata de negá-la, mas ela é antes precedida por uma disponibilidade em deixar-se afetar, uma espécie de prazer que se dá à revelia da consciência, no seu desligamento: "meu corpo não tem as mesmas ideias que eu” (BARTHES, 1983, p. 53). O método é o momento de reordenação, após o corpo ser deslocado pela experiência da leitura: "Há na leitura um movimento iniciado no leve tremor/temor dos 
olhos, que prossegue até ao início dos pés que, debaixo da mesa, balançam. Há no balanço das pernas de quem lê, imóvel, uma impressionante marcha, um atravessar: quem lê, anda" (TAVARES, 2009, p. 63).

Escrito em forma de fragmento, o texto gonçaliano passa ao largo da tagarelice de que falava Barthes, quando se referia ao texto narrativo e longo, como o romance (BARTHES, 1983, p. 37). Sua forma, breve, densa e reflexiva, exige atenção demorada, nesse sentido podendo ser aproximada dos protocolos de leitura exigidos pelo texto moderno. Não obstante esta proximidade, seu texto não parece provocar no leitor o sentimento de perda e desconforto a que se referia Barthes, ao fazer "vacilar as bases históricas, culturais e psicológicas do leitor” (BARTHES, 1983, p. 49).

Estaríamos diante da abdicação da literatura (e da arte) enquanto lugar de resistência, ou, antes, da adesão a outras formas e, talvez, também, noções de resistência? Se a literatura moderna se constituiu como experiência do atrito, apostando na ilegibilidade do texto e em formas de leitura inteligentes e cultas como intensificadoras da experiência, talvez em relação à literatura contemporânea, na qual a de Gonçalo Tavares se inclui, a exigência caminhe no sentido da necessidade de abertura ao heterogêneo e ao diferente, em relação ao qual o leitor terá o trabalho (maior? menor?) de criar um caminho, sem o amparo da presença autoral. Nossa hipótese é que, nesta posição de disponibilidade infinita, é necessário o gesto ético que separa e diferencia, em oposição ao moral, de respeito ao autor.

$\mathrm{Na}$ tentativa de traçar o que pode ser considerado como uma mudança em termos de criação poética, ${ }^{4}$ Marjorie Perloff lembra que a primeira crítica ao poema The waste land, de T. S. Eliot, um dos mais conhecidos da literatura moderna inglesa, foi negativa, justamente pelo uso excessivo da citação e a dificuldade que daí resultava, de acesso à voz do poeta. (PERLOFF, 2010, p. 1). Seu autor, Edgell Rickword, considerava um problema o fato de o poema incluir um conjunto de notas retiradas de outros textos, o que o distanciava da verdadeira essência da poesia: a expressão de uma emoção pessoal. Eliot, ironicamente, nunca mais faria uso da citação, o que não impediu que, quase um século depois de ter sido escrito, The waste land continue a ser o seu poema mais conhecido (PERLOFF, 2010, p. 2-3).

$\mathrm{Na}$ atual era da informação, na qual meios de comunicação transformam radicalmente nossas experiências de tempo e espaço, em que é possível trocar mensagens com pessoas sem saber quem são ou onde estão, as aproximações se estabelecem não mais, necessariamente, por proximidade geográfica, mas de uma forma mais ampla e livre, por afinidade de interesses. A noção de comunidade adquire assim um outro significado, seja na rede, em blogs e sites, seja na impossibilidade infinita de trocas, ocorridas em encontros, residências e projetos comuns ao redor do mundo. Nesse cenário, talvez se esteja assistindo, propõe Perloff, ao deslocamento de uma poética apoiada na noção de resistência, para uma outra apoiada na ideia de diálogo. Um diálogo amplo, que pode incluir textos mais antigos, textos 
em outras mídias, "textos que falam através de outros textos", ou ekphrasis, ${ }^{5}$ permitindo sua participação em um cenário cultural mais amplo.

Talvez seja então necessário refazer a pergunta: "O que importa quem fala?" - e repensar o que hoje ela poderá indicar quanto ao estatuto da voz autoral. Se a sua enunciação designava o desaparecimento do autor como um gesto ético, de ceder iniciativa às palavras, e, por conseguinte, dar possibilidade ao leitor de serem experimentadas plenamente, é preciso reconhecer que os textos que fizeram do desaparecimento autoral uma exigência, não apagaram a presença autoral desse gesto. Vejam-se os exemplos incontornáveis de Rimbaud e Mallarmé. A descoincidência entre sujeito empírico e sujeito autoral remete indubitavelmente a Rimbaud; o mesmo acontece com o desaparecimento elocutório do poeta e o ceder iniciativa às palavras anunciados por Mallarmé. Como nota Agambem:

O autor não está morto, mas pôr-se como autor significa ocupar o lugar de um morto. Existe um sujeito-autor, e, no entanto, ele se atesta unicamente por meio dos sinais da sua ausência. Mas de que maneira uma ausência pode ser singular? E o que significa, para um indivíduo, ocupar o lugar de um morto, deixar as próprias marcas em um lugar vazio? (AGAMBEM, 2007, p. 58).

Mas é possível avançar mais: decorridos longos anos dessas premissas, verifica-se não um diminuir da importância da figura do autor, mas antes seu recrudescimento. É evidente que tal constatação se relaciona com questões de mercado e de mídia que não cabe desenvolver aqui. A citação recoloca, assim, a questão da autoria, pois se é evidente a existência de um sujeito que antecipadamente lê, recorta e cola citações na construção do texto, o que resulta daí é a diluição de uma voz única, subjetiva e autoral. Trata-se, assim, de uma autoria estremecida e porosa, compartilhada, que evidencia acima de tudo o gesto de leitura que a precede: "De certa forma não há sujeito da citação senão em um regime democrático de escrita" (COMPAGNON, 2007, p. 51). Uma escrita atravessada de leituras, que se constitui a partir delas e em nome delas, dando-lhes, todavia, outras vozes e sentidos além daquelas originalmente sabidas.

Na poética gonçaliana, a citação, em suas variadas formas, evidencia um processo de leitura-escritura em que a autoria, distante do esforço investido na negação da influência e da procura de uma voz original, assume e explicita essa influência, nutrindo-se dela:

Escrever como tradução do ler. Uma tradução não apenas incorrecta, errada; mais do que isso: desastrada. Escrevo tentando traduzir entre duas línguas idênticas o que li, mas falho, daí a criatividade; invenção como falha evidente, não na repetição mas na tentativa de passagem de uma coisa para outro lado. Perdi algo na passagem, no transporte, isto é: ganhei algo, porque a mesa que perde uma das suas quatro pernas numa mudança imobiliária, inventa, no mesmo instante, um outro objeto com três pernas (TAVARES, 2009, p.61). 
Insistindo no exercício da escrita como processo de investigação, Tavares sempre fez desse lugar um lugar partilhado, quer pela referência a outros autores em seus textos, quer pela insistência da necessidade de ler. Uma das marcas da poética de Gonçalo M. Tavares, caracteriza-se, desde o começo da sua produção, por um intenso diálogo e cosmopolitismo, na assumida e explícita amplitude de referências.

Quer em entrevistas, quer em eventos literários de que participa, Gonçalo M. Tavares tem sabido preservar a neutralidade quanto a fornecer interpretações de seus textos, além de evitar apreensões totalizantes que possam contribuir para uma definição estável de seu projeto e dos caminhos que este poderá vir a traçar. Contrariando algumas leituras que identificam na poética gonçaliana um desejo de totalidade, seja pela quantidade seja pela diversidade, nossa leitura segue um outro caminho, propondo que se trata de uma obra inacabada, definitivamente inacabada, diria Duchamp, não constrangida por definições e aberta à experimentação:

Os gêneros literários são quase sempre definidos pelo receptor e não pelo emissor, digamos assim. O que me parece preocupante é que o emissor, o escritor, antes de escrever, já se submeta às lógicas de recepção, e portanto se sente na cadeira a pensar: agora vou escrever um romance, agora um poema, agora um conto. Há letras e com elas formo palavras, mas posso escrever o que quiser, ir por qualquer caminho. $\mathrm{O}$ alfabeto não tem gênero literário. Por isso, por mim, tento sentar-me e escrever, simplesmente (TAVARES, 2007, p. 17).

Ademais, sua obra inclui, desde o seu começo, textos de diferentes tonalidades, mais solares, como os Senhores, outros mais neutros e reflexivos, como Breves notas, além de outros mais desencantados, como os $\mathrm{Li}$ vros pretos da tetralogia $O$ Reino ou Uma Viagem à Índia. Como já foi dito no que toca à sua obra, (em processo), é como se estivéssemos na presença de uma "espécie de heteronímia temático-estilística" (MOURÃO, 2012, p. 49). Uma obra em relação à qual a figura autoral mantém-se inapreensível, não por desaparecimento, mas por multiplicação, ao ponto de não ser possível identificar uma voz central que a defina.

Bem se vê que o pacto de leitura que se firma é outro, ao exigir do leitor menos um trabalho na construção de um sentido e mais uma disponibilidade, amparada pela certeza da inexistência do sentido único, sabendo de antemão que os sentidos se constroem na correlação de forças surgidas a cada leitura. Se existe desconforto, será por se tratar de uma obra que não apresenta um quadro de referências estáveis, em forma ou conteúdo. Trata-se de obras que requerem, também, olhares dispostos à inquietação, abertos à possibilidade de leituras precárias e renováveis.

Não parece ser mais possível, hoje, falar de um "espírito do tempo", quer pela dificuldade de encontrar a configuração de uma experiência comum suficientemente abrangente, quer pela percepção de que tal espírito, quando referido, dizia respeito, afinal, a uma experiência localizada, eu- 
ropeia e suas extensões, em um processo de ignorância de outros tempos e experiências variados e concomitantes. O tempo contém tempos, formas distintas de vivenciar experiências outrora consideradas universais. Enfim, um tempo único parece não mais vigorar. A resposta à pergunta "Que importa quem fala?” deverá ser, cada vez mais, plural.

\section{REFERÊNCIAS BIBLIOGRÁFICAS}

AGAMBEM, Giorgio. Profanações. Trad. Selvino J. Assmann. São Paulo: Biotempo, 2007.

BARTHES, Roland. O prazer do texto. Trad. Maria Margarida Barahona. Lisboa, Edições 70, 1983.

BENJAMIN. Walter. Sobre arte, técnica, linguagem e politica. Trad. MOITA, Maria Luz Moita, CRUZ, Maria Amélia, ALBERTO, Manuel. Lisboa: Relógio d'Água, 1992.

COMPAGNON, Antoine. O trabalho da citação. Trad. Cleonice P. B. Mourão. Belo Horizonte: EFMG, 2007.

LLANSOL, Maria Gabriela. Um falcão no punho. 2. ed. Lisboa: Relógio d'Água, 1998.

MOURÃO, Luís. O romance-reflexão segundo Gonçalo M. Tavares. Diacrítica - Revista do Centro de Estudos Humanísticos da Universidade do Minho, Vila Nova de Famalicão: Edições Húmus, n. 25, Jan 2012.

PERLOFF, Marjorie. Un original genius. Poetry by other means in the new century. Chicago: The University of Chicago Press, 2010.

TAVARES, Gonçalo M. Breves notas sobre as ligações. (Llansol, Molder, Zambrano). Lisboa: Relógio d'Água, 2009.

. Ler para ter lucidez. Entrevista concedida a Joca Terron. Revista Entrelivros, edição 29. Setembro 2007.

Recebido para publicação em 20/08/2017

Aprovado em 26/10/2017

\section{NOTAS}

1Professora adjunta da Uerj na Faculdade de Formação de Professores de S. Gonçalo. $\mathrm{Na}$ literatura portuguesa estuda principalmente autores modernos e contemporâneos. Sua pesquisa atual é sobre formas de subjetividade em Vergílio Ferreira e Gonçalo M. Tavares.

$2 \mathrm{O}$ autor publicou anteriormente Breves notas sobre a ciência (2006) e Breves notas sobre o medo (2007). A citação, entretanto, só foi usada em Breves notas sobre as ligações (llansol, molder, zambrano).

3 Giorgio Manganelli (1922-1990) um dos mais conceituados críticos literários do pós-guerra italiano. Membro do movimento vanguardista conhecido como Grupo 63. Autor 
de extensa obra em que se destacam os livros Hilarotragoedia (1964), Letteratura come menzogna (1967), Amore (1981) e Dall'inferno (1985).

4 Consideramos que a escrita em fragmentos presente em muitos dos textos de Gonçalo M. Tavares, inclusive aquele de que nos ocupamos neste trabalho, pode ser equiparada à usada na poesia referida por Perloff.

5 O termo ekphrasis foi e é alvo de várias definições e vários fins, sendo que a sua definição acaba por depender apenas do argumento particular que se discute. Uma definição mais ampla entenderia ekphrasis como uma descrição virtuosa da realidade física (objectos, sentidos, pessoas) com o intuito de evocar uma imagem mental tão intensa como se o objecto real descrito estivesse perante os olhos do leitor. In: Dicionário de Termos Literários. Disponível em: http://edtl.fcsh.unl.pt/business-directory/7085/ecphrasis-/. Acessado em: 20.07.2017 